Perbal: Jurnal Pertanian Berkelanjutan

Volume 10 No.1 Februari 2022

ISSN 2302-6944,e-ISSN 2581-1649

\title{
OPTIMALISASI PEMANFAATAN KOTORAN KELELAWAR TERHADAP PERTUMBUHAN SAMBUNG PUCUK TANAMAN KAKAO KLON M-45
}

\author{
Optimizing the Utilization of Bat Manure on the Growth of the grafting of Cocoa clones M-45 \\ Muhammad Naim ${ }^{*}$ dan Hamdan Sirdam ${ }^{2}$ \\ ${ }^{12)}$ Program Studi Agroteknologi, Fakultas Pertanian, Universitas Cokroaminoto Palopo \\ ${ }^{1 *)}$ naimyusnawati89@gmail.com
}

\begin{abstract}
ABSTRAK
Kakao merupakan salah satu komoditas perkebunan yang peranannya cukup penting bagi perekonomian nasional, khususnya sebagai penyedia lapangan kerja, sumber pendapatan dan devisa negara. Disamping itu kakao juga berperan dalam mendorong pengembangan wilayah dan pengembangan agroindustri, khususnya daerah Sulawesi Tengah, Sulawesi Tenggara, dan Sulawesi Selatan. Sebagai komoditas terpenting ketiga setelah karet dan kelapa sawit, kakao merupakan salah satu sumber utama pendapatan petani. Penelitian ini bertujuan untuk mengetahui: (1) Optimalisasi pemanfaatan kotoran kelelawar terhadap pertumbuhan sambung pucuk tanaman kakao klon M-45. (2) Untuk mengetahui dosis kotoran kelelawar yang efektif terhadap pertumbuhan sambung pucuk tanaman kakao klon M-45. Penelitian ini dilaksanakan di Lahan Percobaan I Fakultas Pertanian, Universitas Cokroaminoto Palopo, di Kelurahan To' Bulung, Kecamatan Bara, Kota Palopo, dimulai bulan Desember 2019 sampai Februari 2020. Penelitian ini menggunakan Rancangan Acak Kelompok (RAK). Penelitian ini terdiri dari 6 perlakuan dan 4 ulangan, sehingga dalam penelitian ini terdapat 24 unit percobaan, setiap unit percobaan terdapat 2 sampel tanaman sehingga terdapat 48 sampel tanaman pengamatan. Percobaan yang diberikan yaitu, P0: Tanpa perlakuan, P1: Pemberian kotoran kelelawar 225 gram, P2: Pemberian kotoran kelelawar 250 gram, P3: Pemberian kotoran kelelawar 275 gram, P4: Pemberian kotoran kelelawar 300 gram, P5: Pemberian kotoran kelelawar 325 gram. Hasil penelitian ini menunjukkan pengaruh tidak nyata terhadap pertumbuhan sambung pucuk tanaman kakao Klon M-45. Perlakuan P5 dengan dosis kotoran kelelawar 325 gram memberi respon terbaik pada pertumbuhan panjang tunas: $13,88 \mathrm{~cm}$, jumlah daun: 14,50 helai, diameter tunas: $1,08 \mathrm{~cm}$. Hari muncul tunas terbaik yaitu pada perlakuan P2: 16,00. Hal ini diduga karena terpenuhinya unsur hara terhadap pertumbuhan sambung pucuk tanaman kakao klon M-45.
\end{abstract}

Kata kunci : tanaman kakao, sambung pucuk, kotoran kelelawar

\begin{abstract}
Cocoa is one of the plantation commodities whose role is quite important for the national economy, especially as a provider of employment, a source of income and foreign exchange. Besides that, cocoa also plays a role in encouraging regional development and agro-industry development, especially in Central Sulawesi, Southeast Sulawesi, and South Sulawesi. As the third most important commodity after rubber and oil palm, cocoa is one of the main sources of income for farmers. This study aims to determine: (1) Optimizing the use of bat manure on the growth of shoot grafting of the M-45 clone of cocoa plants. (2) To determine the effective dose of bat manure on the growth of shoot grafting of M-45 clones of cocoa. This research was conducted at Experimental Field I, Faculty of Agriculture, Cokroaminoto University, Palopo, in To' Bulung Village, Bara District, Palopo City, starting from December 2019 to February 2020. This study used a Randomized Block Design (RAK). This study consisted of 6 treatments and 4 replications, so that in this study there were 24 experimental units, each experimental unit contained 2 plant samples so that there were 48 samples of observed plants. The treatments namely, P0: No treatment, P1: 225 grams of bat manure, P2: 250 grams of bat manure, P3: 275 grams of bat manure, P4: 300 grams of bat manure, P5: 325 grams of bat manure. The results of this study showed no significant effect on the growth of the buds of the M45 clone of cocoa plants. P5 treatment with a dose of 325 grams of bat dung gave the best response to the growth of shoot length: $13.88 \mathrm{~cm}$, number of leaves: 14.50 strands, shoot diameter: $1.08 \mathrm{~cm}$. The day the best shoots appeared was treatment P2: 16.00. This is due to the fulfillment of nutrients for the growth of shoot grafting of cocoa clones M-45.
\end{abstract}

Keywords: cocoa plants, grafting, bat manure 
Perbal: Jurnal Pertanian Berkelanjutan

Fakultas Pertanian Universitas Cokroaminoto Palopo

\section{PENDAHULUAN}

Kakao ialah bahan baku utama dalam pembuatan coklat dan satu dari komoditas perkebunan andalan nasional. Komoditas kakao akan terus dikembangkan dalam rangka usaha meningkatkan devisa negara melalui kegiatan ekspor serta mengoptimalkan penghasilan petani kakao. Iklim dan topografi tanah Indonesia sesuai untuk pengembangan tanaman kakao. Di Indonesia tanaman kakao diperkenalkan oleh orang Spanyol pada tahun 1560 di Minahasa dan Sulawesi (Pusat Penelitian Kopi dan Kakao Indonesia, 2012 dalam Damanik, dkk., 2013). Perkembangan kakao semakin pesat, sehingga sejak tahun 1951 kakao menjadi salah satu komoditas perkebunan yang penting di Indonesia (Rizaldi, 2013).

Produksi kakao di Sulawesi Selatan sejak lima tahun terakhir mengalami fluktuasi, berdasarkan data dari Badan Pusat Statistika (BPS) (2018) bahwa produksi kakao pada tahun 2014 sebesar $807 \mathrm{~kg} / \mathrm{ha}$, pada tahun 2015 mengalami peningkatan $814 \mathrm{~kg} / \mathrm{ha}$, kemudian meningkat pada tahun 2016 menjadi $865 \mathrm{~kg} / \mathrm{ha}$, selanjutnya tahun 2017 dan 2018 mengalami penurunan $773 \mathrm{~kg} / \mathrm{ha}$ dan $730 \mathrm{~kg} / \mathrm{ha}$ (BPS, 2018).
Adanya fluktuasi produksi pada tanaman kakao setiap tahunnya disebabkan kualitas dan pengembangan bibit tanaman kakao petani masih kurang efisien, baik dalam hal waktu maupun teknis pelaksanaannya, sehingga kemampuan penyediaan bibit kakao unggul masih terbatas dan harganya pun relatif tinggi. Untuk meningkatkan kualitas dan pengembangan bibit tanaman kakao, maka perlu dilakukan teknik perbanyakan bibit kakao secara vegetatif.

Salah satu keistimewaan bibit kakao hasil perbanyakan dengan cara vegetatif yaitu tanaman yang dihasilkan mempunyai kualitas yang tinggi yaitu tidak menyimpang dari sifat induknya dan masa panen lebih cepat. Salah satu teknik perbanyakan vegetatif yaitu dengan cara sambung pucuk. Bibit tanaman hasil dari perbanyakan vegetatif asal sambungan akan menghasilkan pertumbuhan dan produksi yang lebih seragam dibandingkan dengan perbanyakan generatif.

Dalam penelitan Limbongan dan Djufry (2013) bahwa perbanyakan bibit kakao secara vegetatif bertujuan untuk memperoleh bibit yang bermutu tinggi, baik kuantitas maupun kualitasnya. Pemilihan teknologi perbanyakan bibit 
kakao secara vegetatif perlu mempertimbangkan ketersediaan entres, kemampuan sumber daya manusia, tingkat keberhasilan sambungan, jumlah kebutuhan bibit, dan ketersediaan fasilitas penunjang. Beberapa alternatif pilihan yang tersedia antara lain teknologi setek, okulasi, sambung pucuk, sambung samping, dan somatik embriogenesis.

Teknologi perbanyakan vegetatif yang paling banyak diterapkan petani kakao adalah sambung pucuk. Teknologi ini mudah dilakukan, bahan-bahan yang digunakan mudah didapat, dan biayanya murah. Sambung pucuk merupakan teknik perbanyakan tanaman dengan menggabungkan batang bawah dari pohon induk terseleksi dan adaptif di daerah setempat dengan batang atas dari varietas unggul yang berproduksi tinggi. Sambung pucuk juga ditujukan untuk memperbaiki sifat batang atas dan memperoleh tanaman yang cepat berproduksi.

Bibit tanaman hasil dari perbanyakan vegetatif asal sambungan akan menghasilkan pertumbuhan dan produksi yang lebih seragam dibandingkan dengan perbanyakan generatif. Perbanyakan secara sambung pucuk persentase tumbuh lebih tinggi jika dibandingkan dengan cara perbanyakan vegetatif lainnya, untuk menunjang perbanyakan kakao secara vegetatif utamanya sambung pucuk maka perlu pemberian unsur hara organik.

Pupuk organik, merupakan pupuk yang berupa senyawa organik. Kebanyakan pupuk alam tergolong pupuk organik, seperti pupuk kandang, pupuk kompos, dan pupuk guano. Manfaat pupuk dalam hal ini adalah memperbaiki struktur tanah dari padat menjadi gembur. Pemberian pupuk organik terutama dapat memperbaiki struktur tanah dengan menyediakan ruang pada tanah untuk udara dan air. Manfaat lain adalah mengurangi erosi pada permukaan tanah, berfungsi sebagai penutup tanah dan memperkuat struktur tanah di bagian permukaan sehingga tanah tidak mudah tergerus air. Kotoran kelelawar yang sering disebut guano, ternyata menyimpan potensi besar sebagai pupuk organik. Sekitar 1.000 gua di Indonesia diprediksi berpotensi menjadi salah satu solusi atas masalah kekurangan pasokan pupuk di negara kita saat ini. Salah satu penelitian yang mampu membuktikan kegunaan guano sebagai bahan dasar pupuk organic (Suwarno dan Idris, 2007).

Pupuk guano dapat memperbaiki kesuburan tanah, pupuk guano 
Perbal: Jurnal Pertanian Berkelanjutan

Fakultas Pertanian Universitas Cokroaminoto Palopo

mengandung $7-17 \% \mathrm{~N}, 8-15 \% \mathrm{P}$, dan $1,5-$ 2,5\% K. N sangat dibutuhkan tanaman untuk mendukung pertumbuhan vegetatif tanaman. Selanjutnya P merangsang pertumbuhan akar dan pembungaan, $\mathrm{K}$ terutama berperan untuk memperkuat jaringan tanaman terutama batang tanaman (Suwarno dan Idris, 2007). Syofiani, dkk., (2017) menjelaskan bahwa pemberian pupuk guano dapat menaikkan $\mathrm{pH}$ tanah, KTK tanah, kadar N, P, K dan P tersedia.

\section{METODE PENELITIAN}

\section{Tempat dan Waktu}

Penelitian ini dilaksanakan di

Lahan Percobaan I Fakultas Pertanian, Universitas Cokroaminoto Palopo, di Kelurahan To' Bulung, Kecamatan Bara, Kota Palopo, dimulai bulan Desember 2019 sampai Februari 2020.

\section{Bahan dan Alat}

Bahan yang digunakan dalam penelitian ini adalah bibit tanaman kakao klon M-45, entres, plastik sungkup, polybag ukuran $15 \times 20 \mathrm{~cm}$, air dan kotoran kelelawar.

Alat yang digunakan dalam penelitian ini adalah pisau okulasi, gunting pangkas, mistar, kamera, ember, cangkul, parang, palu, sabit, papan penelitian, label perlakuan, rotan, paku, bambu, plastik UV, paranet, sekop dan alat tulis menulis

\section{Metode Percobaan}

Metode yang digunakan dalam penelitian ini yaitu Rancangan Acak Kelompok (RAK). Penelitian ini terdiri dari 6 perlakuan dan 4 ulangan, sehingga dalam penelitian ini terdapat 24 unit percobaan, setiap unit percobaan terdapat 2 sampel tanaman sehingga terdapat 48 unit sampel tanaman pengamatan. Adapun perlakuan dalam penelitian ini yaitu, $\mathrm{P0}=$ Tanpa perlakuan, $\mathrm{P} 1=$ Pemberian kotoran kelelawar 225 gram, P2 = Pemberian kotoran kelelawar 250 gram, $\mathrm{P} 3=$ Pemberian kotoran kelelawar 275 gram, P4 = Pemberian kotoran kelelawar 300 gram, P5 = Pemberian kotoran kelelawar 325 gram.

Data hasil penelitian dianalisis dengan menggunakan analisis sidik ragam berdasarkan uji taraf 5\% dan apabila terdapat perbedaan yang nyata dilanjutkan dengan uji Beda Nyata Jujur $(\mathrm{BNJ})$ taraf $5 \%$.

\section{Metode Pelaksanaan}

Percobaan dilaksanan di rumah pembibitan. Persiapan rumah pembibitan yaitu dengan cara memotong bambu berukuran $200 \mathrm{~cm}$ sebanyak enam potong dan memotong bambu berukuran $250 \mathrm{~cm}$ 
sebanyak dua potong, serta memotong bambu untuk dijadikan palang yang berukuran $350 \mathrm{~cm}$. Kemudian palang tersebut dihubungkan dengan tiang yang berukuran $250 \mathrm{~cm}$ untuk membentuk rangka. Setelah rangka terbentuk kemudian ditegakkan, selanjutnya tiang yang berukuran $200 \mathrm{~cm}$ ditegakkan masing-masing disisi kiri dan kanan tiang utama. Kemudian belah bambu menjadi dua bagian yang berukuran $200 \mathrm{~cm}$ sebanyak sepuluh bagian. Setelah belahan tersebut dipasang untuk menghubungkan sisi kiri dan kanan tiang utama dan sekaligus tempat dudukan plastik sebagai atap. Setelah semua terhubung selanjutnya memasang plastik dan daun kelapa sebagai atap dan memasang paranet disekeliling rumah penelitian untuk menghindari masuknya hewan ternak dan hama pengganggu lainnya.

Penyambungan dilakukan dengan memotong batang bawah dan menyisakan 3-8 helai daun. Potong agak miring agar hasilnya tidak berserat, batang bawah di belah sedalam 2-3 cm. Entres disayat dengan panjang sayatan 2-3 cm. Model sayatan yang baik sama panjang antara sayatan sebelah kiri dan sebelah kanan sayatan membentuk kapak. Entres dipotong dengan menyisakan 2-4 mata tunas dan disisipkan kedalam belahan batang bawah dengan menarik salah satu sisi belahan. Apabila entres lebih besar dari batang bawah atau sebaliknya, posisi salah satu sisi entres harus rapat dan rata dengan batang bawah. Pengikatan dilakukan dari arah atas ke bawah agar entres tidak bergerak dan sungkup menggunakan plastik transparan.

\section{Parameter Pengamatan}

Pengamatan tanaman dilakukan mulai pengamatan panjang tunas, diameter batang, jumlah daun dan hari muncul tunas dilakukan 1 kali dalam 2 minggu. Adapun parameter pengamatan dalam penelitian ini yaitu: panjang tunas (cm), jumlah daun (helai), diameter tunas (cm), hari muncul tunas (hari).

\section{Analisis Data}

Data yang telah dikumpulkan ditabulasi, kemudian dianalisis keragamannya. Jika hasil analisis ragam terdapat pengaruh yang nyata pada taraf $5 \%$ diantara perlakuan yang diuji, maka dilakukan uji lanjut dengan menggunakan uji Beda Nyata Jujur (BNJ) pada taraf yang sama.

\section{HASIL DAN PEMBAHASAN}

\section{Hasil}

Panjang Tunas (cm) 
Perbal: Jurnal Pertanian Berkelanjutan

Fakultas Pertanian Universitas Cokroaminoto Palopo

Hasil rata-rata panjang tunas sambung pucuk tanaman kakao klon M45 dapat dilihat pada gambar 1.

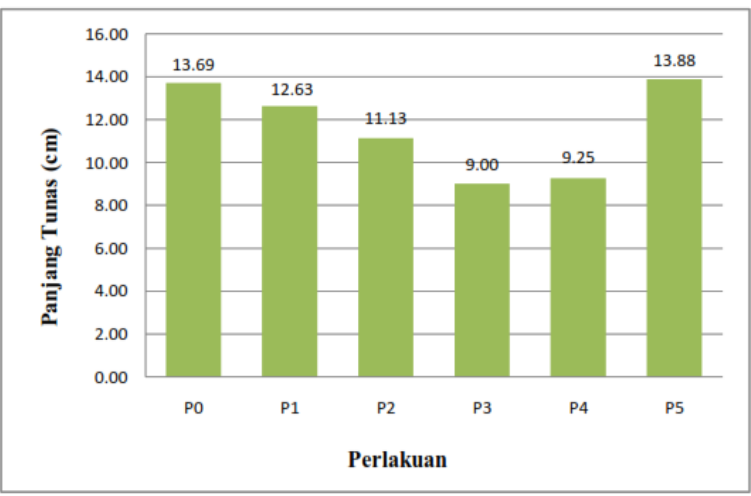

Gambar 1. Diagram rata-rata panjang tunas sambung pucuk tanaman kakao klon M-45 pada pemberian kotoran kelelawar.

Diagram diatas memperlihatkan bahwa pemberian kotoran kelelawar terhadap pertumbuhan sambung pucuk tanaman kakao klon M-45, menghasilkan rata-rata panjang tunas terbaik yang ditunjukan pada perlakuan P5 (kotoran kelelawar 325 gram) dengan nilai rata-rata $13,88 \mathrm{~cm}$, terbaik kedua ditunjukan pada perlakuan P0 (tanpa perlakuan) dengan rata-rata $13,69 \mathrm{~cm}$, terbaik ketiga pada perlakuan P1 (kotoran kelelawar 225 gram) dengan rata-rata $12,63 \mathrm{~cm}$, terbaik keempat pada perlakuan P2 (kotoran kelelawar 250 gram) dengan rata-rata 11,13 $\mathrm{cm}$, kemudian terbaik kelima terdapat pada perlakuan P4 (kotoran kelelawar 300 gram) dengan rata-rata $9,25 \mathrm{~cm}$, sedangkan untuk hasil terendah ditunjukan pada perlakuan P3 (kotoran kelelawar 275 gram) dengan ratarata $9,00 \mathrm{~cm}$.

\section{Jumlah Daun}

Hasil rata-rata jumlah daun sambung pucuk tanaman kakao klon M45 dapat dilihat pada gambar 2 .

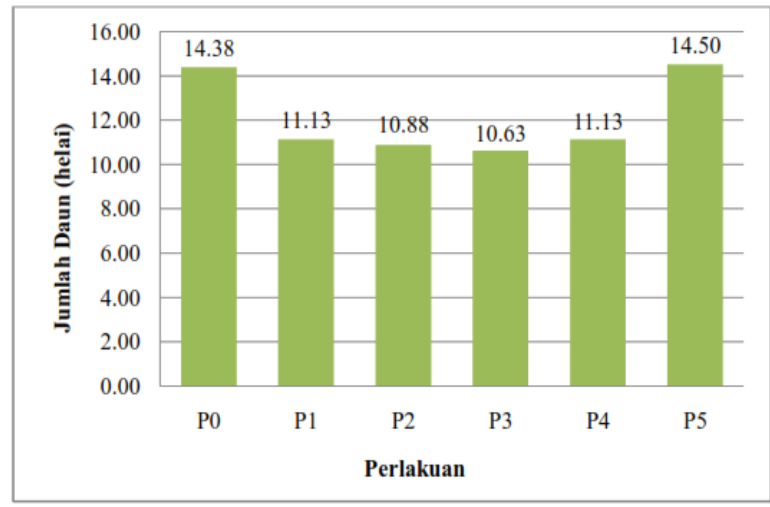

Gambar 2. Diagram rata-rata jumlah daun sambung pucuk tanaman kakao klon M-45 pada pemberian kotoran kelelawar.

Diagram diatas memperlihatkan bahwa pemberian kotoran kelelawar terhadap pertumbuhan sambung pucuk tanaman kakao klon M-45, menghasilkan rata-rata jumlah daun terbaik ditunjukan pada perlakuan P5 (kotoran kelelawar 325 gram) dengan nilai rata-rata 14,50 helai, terbaik kedua ditunjukan pada perlakuan P0 (tanpa perlakuan) dengan rata-rata 14,38 helai, terbaik ketiga pada perlakuan P1 (kotoran kelelawar 225 gram) dan P4 (kotoran kelelawar 300 gram/tanaman) dengan rata-rata 11,13 helai, terbaik keempat pada perlakuan P2 (kotoran kelelawar 250 gram) dengan rata-rata 10,88 
helai, sedangkan untuk hasil terendah ditunjukan pada perlakuan P3 (kotoran kelelawar 275 gram) dengan rata- rata 10,63 helai.

\section{Diameter Tunas}

Hasil rata-rata diameter tunas sambung pucuk tanaman kakao klon M-45 dapat dilihat pada gambar 3 .

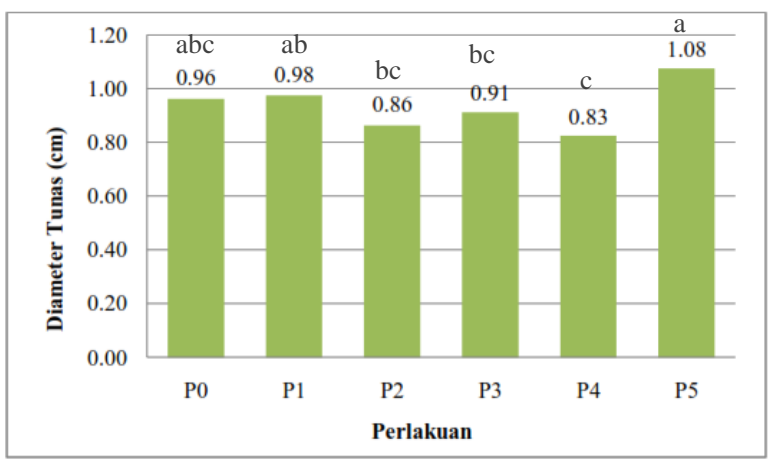

Gambar 3. Diagram rata-rata diameter tunas sambung pucuk tanaman kakao klon M-45 pada pemberian kotoran kelelawar.

Diagram diatas memperlihatkan bahwa pemberian kotoran kelelawar terhadap pertumbuhan sambung pucuk tanaman kakao klon M-45, menghasilkan rata-rata diameter tunas pada pemberian kotoran kelelawar terhadap pertumbuhan sambung pucuk tanaman kakao klon M45 yang berbeda dan hasil yang berbedabeda. Diagram diatas menunjukan rata-rata diameter tunas terbaik ditunjukan pada perlakuan P5 (kotoran kelelawar 325 gram) dengan nilai rata-rata $1,08 \mathrm{~cm}$, terbaik kedua ditunjukan pada perlakuan P1 (kotoran kelelawar 225 gram) dengan rata-rata 0,98 $\mathrm{cm}$, terbaik ketiga pada perlakuan P0 (tanpa perlakuan) dengan rata-rata $0,96 \mathrm{~cm}$, terbaik keempat pada perlakuan P3 (kotoran kelelawar 275 gram) dengan rata-rata 0,91 $\mathrm{cm}$, kemudian terbaik kelima terdapat pada perlakuan P2 kotoran kelelawar 250 gram) dengan rata-rata $0,86 \mathrm{~cm}$, sedangkan untuk hasil terendah ditunjukan pada perlakuan P4 (kotoran kelelawar 300 gram) dengan rata-rata $0,83 \mathrm{~cm}$.

\section{Hari Muncul Tunas}

Hasil rata-rata hari muncul tunas sambung pucuk tanaman kakao klon M45 dapat dilihat pada gambar 4 .

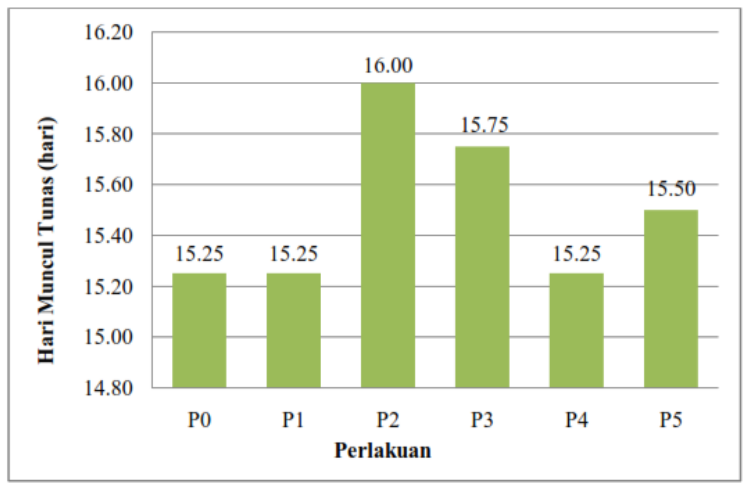

Gambar 4. Diagram rata-rata hari muncul tunas sambung pucuk tanaman kakao klon M-45 pada pemberian kotoran kelelawar.

Diagram diatas memperlihatkan bahwa pertumbuhan sambung pucuk tanaman kakao klon M-45, menghasilkan rata-rata hari muncul tunas yang berbedabeda. Diagram diatas menunjukan ratarata hari muncul tunas terbaik ditunjukan 
Perbal: Jurnal Pertanian Berkelanjutan

Fakultas Pertanian Universitas Cokroaminoto Palopo

pada perlakuan $\mathrm{P} 0, \mathrm{P} 1$ dan $\mathrm{P} 4$ dengan nilai rata-rata 15,25 hari, terbaik kedua ditunjukan pada perlakuan P5 dengan rata-rata 15,50 hari, terbaik ketiga pada perlakuan P3 dengan rata-rata 15,75 hari, sedangkan untuk hasil terendah ditunjukan pada perlakuan $\mathrm{P} 2$ dengan rata-rata 16,00 hari.

\section{Pembahasan}

Berdasarkan hasil penelitian pemberian kotoran kelelawar terhadap pertumbuhan sambung pucuk tanaman kakao klon M-45 yang telah diolah melalui analisi sidik ragam telah diperoleh hasil yang tidak berpengaruh nyata terhadap parameter panjang tunas, jumlah daun, umur hari muncul tunas, sedangkan diameter tunas berpengaruh nyata. Hal ini diduga disebabkan karena penyerapan unsur hara belum maksimal karena ada beberapa faktor, yang pertama penelitian berlangsung pada waktu musim hujan sehingga penyerapan unsur terkendala dengan tergenangnya lahan penelitian. Parameter panjang tunas yang terbaik ditunjukkan pada perlakuan P5 $(13,88 \mathrm{~cm})$ dengan kotoran kelelawar 325 gram dibandingkan dengan perlakuan lainnya. Hal ini diduga karena jumlah dosis pada P5 telah menjadi dosis yang lebih tepat untuk meningkatkan pertumbuhan sambung pucuk tanaman kakao klon M45 karena kotoran kelelawar yang berasal dari bahan organik mampu memperbaiki struktur tanah dan memiliki kandungan unsur nitrogen $(\mathrm{N})$ yang sangat tinggi. Hal ini sesuai dengan pendapat Hanafiah (2007) dalam Agustin dkk. (2014), yang menyatakan bahwa bahan organik ini memberikan kondisi yang sesuai untuk tanaman dengan memperbaiki struktur tanah menjadi remah, meningkatkan kemampuan menahan air serta tidak berlebihan, serta kelembapan dan temperatur tanah menjadi stabil hingga memudahkan tanaman menyerap unsur hara.

Parameter jumlah daun yang terbaik ditunjukkan pada perlakuan P5 (14,50 helai) dengan kotoran kelelawar 325 gram dibandingkan dengan perlakuan lainnya. Karena unsur hara nitrogen yang diserap oleh tanaman kakao dari kotoran kelelawar terserap dengan baik dan dapat memenuhi kebutuhan dari tanaman kakao pada proses pembentukan daun. Menurut Lingga dan Marsono (2001) dalam Daryadi dan Ardian (2017), bahwa penambahan unsur hara nitrogen $(\mathrm{N})$ dapat merangsang pertumbuhan vegetatif yaitu cabang, batang dan daun yang merupakan 
komponen penyusun asam amino, protein dan pembentukan protoplasma sel.

Pengamatan pada parameter diameter tunas terbaik ditunjukkan pada perlakuan P5 $(1,08 \mathrm{~cm})$ dengan kotoran kelelawar 325 gram dibandingkan dengan perlakuan lainnya. Diameter tunas sangat dipengaruhi kadungan unsur hara yang terkandung pada kotoran kelelawar untuk menunjang pertumbuhan sambung pucuk tanaman kakao. Kotoran kelelawar memiliki tingkat nitrogen terbesar setelah kotoran merpati. Namun menduduki urutan pertama dalam kadar unsur fosfat, dan menduduki urutan tiga terbesar bersama kotoran sapi perah dalam kadar kalium (Bustami dan Rosa, 2017).

Parameter Pengamatan pada hari muncul tunas sambung pucuk tanaman kakao dengan memberikan hasil pada perlakuan P0, P1 dan P4 yang memperlihatkan kemunculan tunas pada hari ke 15 hari setelah sambung. Hal ini dipengaruhi oleh kandungan unsur hara yang tersedia dan dapat diserap oleh sambung pucuk tanaman kakao, sesuai pernyataan Riodevrizo (2010), bahwa sel-sel kambium bersifat meristematis yang berarti mampu membelah diri dan membentuk sel baru. Jika pertemuan kabium pada klon batang atas dan batang bawah semakin banyak, maka penyambungan akan semakin berhasil.

\section{KESIMPULAN DAN SARAN}

\section{Kesimpulan}

Berdasarkan hasil penelitian dan analisis sidik ragam pemberian kotoran kelelawar terhadap pertumbuhan sambung pucuk tanaman kakao klon M-45 diperoleh hasil yang tidak berpengaruh nyata terhadap parameter panjang tunas, jumlah daun, umur hari muncul tunas, sedangkan diameter tunas berpengaruh nyata. Dari beberapa perlakuan diperoleh nilai rata- rata yang berbeda-beda setiap dosis kotoran kelelawar, P5 dengan dosis kotoran kelelawar 325 gram pada panjang tunas, jumlah daun dan diameter tunas memberikan pengaruh terbaik hal ini dikarenakan jumlah dosis ada P5 telah menjadi dosis yang lebih tepat untuk meningkatkan pertumbuhan sambung pucuk tanaman kakao klon M-45. Sementara parameter pengamatan pada hari muncul tunas sambung pucuk tanaman kakao memberikan pengaruh perlakuan terbaik pada P0, P1 dan P4 yang memperlihatkan kemunculan tunas pada hari ke 15 setelah sambung.

\section{Saran}

Berdasarkan hasil penelitian sebaiknya pada penelitian selanjutnya 
Perbal: Jurnal Pertanian Berkelanjutan

Fakultas Pertanian Universitas Cokroaminoto Palopo

disarankan mengkombinasikan dengan

pupuk yang lain dan memperhatikan

dosis yang diberikan pada saat akan

melakukan penelitian karena akan

berpengaruh pada hasil penelitian.

\section{DAFTAR PUSTAKA}

Agustin, A. D., Riniarti, M. dan Duryat. (2014). Pemanfaatan Limbah Serbuk Gergaji dan Sekam Padi Sebagai Media Sapih untuk Cempaka Kuning (Michelia champaca). Jurnal Sylva Lestari. Vol. 2 No. 3, September 2014 (49-58).

Badan Pusat Statistika. (2018). Produksi Tanaman Kakao di Sulawesi Selatan. BPS Sulawesi Selatan.

Bustami dan E. Rosa. (2017). Kajian Efektivitas Pemberian Pupuk Guano dan Biochar terhadap Produksi dan Serapan Hara Tanaman Padi. Universitas Abulyatama. Jurnal Agrotek Lestari. Vol. 4 No.2.

Damanik H.F, Ginting J. dan Irsal. (2013). Respons Pertumbuhan Bibit Kakao (Theobroma Cacao L.) terhadap Beberapa Komposisi Kompos Kulit Buah Kakao dengan Subsoil Ultisol dan Pupuk Daun. Jurnal Online Agroekoteknologi, Vol.2, No.1: 162171.

Daryadi. dan Ardian. (2017). Pengaruh Pemberian Kompos Ampas Tahu dan Pupuk NPK terhadap Pertumbuhan Bibit Kakao (Theobroma cacao L.). di akses pada 05 September 2020 : https://media.neliti.com/media/ publications/201967-none.pdf.
Hanafiah, K. A. (2007). Dasar-dasar Ilmu Tanah. Raja Grafindo Persada. Jakarta. 358 p.

Limbongan, J. F. dan Djufry. (2013). Pengembangan Teknologi Sambung Pucuk Sebagai Alternatif Pilihan Perbanyakan Bibit Kakao. Jurnal Penelitian dan Pengembangan Pertanian.

Lingga, P dan Marsono. (2001). Petunjuk Penggunaan Pupuk. Penebar Swadaya. Jakarta.

Rizaldi. (2013). Budidaya Tanaman Kakao. Ganesha. Jakarta.

Riodevriza. (2010). Pengaruh Umur Pohon Induk terhadap Keberhasilan Stek dan Sambungan Shorea selanica BI. Departemen Silvikultur. Fakultas Kehutanan Institut Pertanian Bogor. Bogor.

Siregar, T. H.S,. Slamet R., dan Laeli N., (2010). Budidaya Cokelat. Penebar Swadaya. Jakarta.

Suwarno dan K. Idris. (2007). Potensi dan Kemungkinan Penggunaan Guano Secara Langsung Sebagai Pupuk di Indonesia. Jurnal Tanah dan Lingkungan, 9 (1): 37-43.

Syofiani, Riza dan Giska, O. (2017). Aplikasi Pupuk Guano dalam Meningkatkan Unsur Hara N, $P, \quad K$ dan Pertumbuhan Tanaman Kedelai pada Media Tanam Tailing Tambang Emas. Seminar Nasional 2017 Fak. Pertanian UMJ. Fakultas Pertanian. STIPER Sawahlunto Sijunjung. 98103. 